Research Article

\title{
Uneven Precipitation Behavior during the Solutionizing Course of Al-Cu-Mn Alloys and Their Contribution to High Temperature Strength
}

\author{
Jinlong Chen, Hengcheng Liao $(\mathbb{D}$, and Heting Xu \\ School of Materials Science and Engineering, Jiangsu Key Laboratory for Advanced Metallic Materials, Southeast University, \\ Nanjing 211189, China
}

Correspondence should be addressed to Hengcheng Liao; hengchengliao@seu.edu.cn

Received 16 April 2018; Accepted 11 June 2018; Published 29 July 2018

Academic Editor: Pavel Lejcek

Copyright ( 2018 Jinlong Chen et al. This is an open access article distributed under the Creative Commons Attribution License, which permits unrestricted use, distribution, and reproduction in any medium, provided the original work is properly cited.

The dispersoid precipitation behavior during the solutionizing and aging of Al- $x \mathrm{wt} . \% \mathrm{Cu}-1.0 \mathrm{wt} . \% \mathrm{Mn}$ alloys $(x=2.0,4.5$, and 7.5$)$ and contribution to mechanical properties were investigated using tensile testing and microstructural characterization. A shell-core structure of primary $\alpha$ - $\mathrm{Al}$ dendrites is found in $\mathrm{Al}-\mathrm{Cu}-\mathrm{Mn}$ alloys, in which the $\mathrm{Cu}$ content in the shell is higher than that in the core. The area of shell zone (Cu-rich) increases with an increase in $\mathrm{Cu}$ content in the alloy. Large amounts of fine dispersoid $\mathrm{Al}-\mathrm{Cu}-\mathrm{Mn}$ particles precipitate in solution. An alloy with low $\mathrm{Cu}$ content results in only the $T_{\mathrm{Mn}}\left(\mathrm{Al}_{20} \mathrm{Cu}_{2} \mathrm{Mn}_{3}\right)$ particles being precipitated. However, in an alloy with high $\mathrm{Cu}$ content, $\mathrm{AlCu}_{3} \mathrm{Mn}_{2}$ particles are first found to precipitate beside $T_{\mathrm{Mn}}$. However, this precipitation behavior is uneven. The precipitation zones in the solution microstructure are consistent with the $\mathrm{Cu}$-rich regions in the as-cast microstructure. A number of fine particles (dozens nanometer in size) are first found to precipitate on the rod-like $T_{\mathrm{Mn}}$ particles during the aging phase. The redissolution and granulation of the eutectic $\mathrm{CuAl}_{2}$ phase during the solutionizing process result in the formation of particle-free bands between the precipitation zones. The tension test at $300^{\circ} \mathrm{C}$ demonstrates that the increase in high temperature strength is due to the dispersoid precipitation during solutionizing, and the precipitation behavior in the aging phase has little or no effect, however, largely improves the tensile strength at room temperature. High temperature strength is significantly increased with an increase in $\mathrm{Cu}$ content, which correlates to an increase in number and decrease in size of $T_{\mathrm{Mn}}$ and $\mathrm{AlCu}_{3} \mathrm{Mn}_{2}$ particles.

\section{Introduction}

Because of their good high temperature performance, $\mathrm{Al}-\mathrm{Cu}-$ Mn alloys, such as 2519 and 2219 as well as A2219, have been used in structural parts for auto and space vehicles working at higher temperature environment [1-4]. In order to further improve the high-temperature mechanical properties, controlling the size and number of strengthening precipitates with high thermal stability is of great importance.

In $\mathrm{Al}-\mathrm{Cu}-\mathrm{Mn}$ alloys, the main strengthening phases at high temperature have been proposed to be the $T_{\mathrm{Mn}}$ and $\theta$ phases. For $2 \times 24$ alloys, the interaction between the dislocation motion and dispersoid precipitates of $T_{\mathrm{Mn}}$ $\left(\mathrm{Al}_{20} \mathrm{Cu}_{2} \mathrm{Mn}_{3}\right)$ and $\theta\left(\mathrm{CuAl}_{2}\right)$ phases play key roles in strengthening at high temperature [5-8]. For the $2 \times 24$ alloys (Al-Cu-Mg-Mn alloys), large amounts of rod-like T-phase $\left(\mathrm{Al}_{20} \mathrm{Cu}_{2} \mathrm{Mn}_{3}\right)$ dispersoid particles are precipitated in ingot homogenization or solution treatment processes $[9,10]$. Chen et al. [11] reported that the overwhelming majority of particles of the $T_{\mathrm{Mn}}$ phase take a shape of a rod in the $\mathrm{Al}-5 \mathrm{Cu}-1 \mathrm{Mn}$ alloy after solutionizing. Chen et al. [12] produced $\mathrm{Al}-4.6 \mathrm{Cu}-\mathrm{Mn}$ ribbons using melt spinning, and during this process, rod-like $T_{\mathrm{Mn}}$ dispersoids with a diameter of $120-160 \mathrm{~nm}$ formed during the aging process at $190^{\circ} \mathrm{C}$. The work of Wang et al. [13] was in agreement, reporting a rod-like $T_{\mathrm{Mn}}$ phase in $\mathrm{Al}-\mathrm{Cu}-\mathrm{Mn}$ alloys that have the lattice parameters $a=2.41 \mathrm{~nm}$, $b=1.25 \mathrm{~nm}, c=0.78 \mathrm{~nm}$. Using CBED (convergent beam electron diffraction), Park and Kim [14] determined the structure parameters of the $T_{\mathrm{Mn}}$ phase of $a=2.345 \mathrm{~nm}$, 
$b=1.183 \mathrm{~nm}$, and $c=0.729 \mathrm{~nm}$. Recently, Shen et al. [10] proposed that the $T_{\mathrm{Mn}}$ phase belongs to a space group of BBMM (Brownian bridge movement model) with lattice

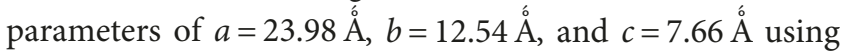
near-atomic resolution chemical mapping. Feng et al. [9] adopted HRTEM and high-angle annular dark-field scanning transmission electron microscopy (HAADF-STEM) to confirm that the $T_{\mathrm{Mn}}$ phase has an orthorhombic structure. Many studies report that the dispersoid $\mathrm{Al}-\mathrm{Cu}-\mathrm{Mn}$ compound particles precipitated during the solutionizing are the $T_{\mathrm{Mn}}$ phase, but another crystal structure of an $\mathrm{Al}-\mathrm{Cu}-\mathrm{Mn}$ compound with formula $\mathrm{AlCu}_{3} \mathrm{Mn}_{2}$ was proposed as a single-phase system using X-ray and neutron diffractometer traces [15]. There are many reports in the literature focusing on the crystal structure of $\mathrm{Al}-\mathrm{Cu}-\mathrm{Mn}$ precipitates. However, the conditions during precipitation from a supersaturated aluminum solution and strengthening effect are not understood and require further study.

PFZ (precipitation-free zone) often occurs at the grain boundaries in $\mathrm{Al}-\mathrm{Cu}$ alloys. It is widely accepted that it is the escaping of both the vacancies and solute atoms of $\mathrm{Cu}$ into the grain boundary during aging course that leads to the formation of PFZ. The formation of PFZs has an important influence on mechanical properties, especially on antistress corrosion property. Li et al. [16] reported that the width of the PFZs became larger with increasing aging time of the Al$\mathrm{Zn}-\mathrm{Mg}-\mathrm{Sc}-\mathrm{Zr}$ alloy. Muntiz and Cotler [17] thought that the smaller the width of PFZs is, the higher the tensile strength is. Both the precipitation behaviors of $T_{\mathrm{Mn}}$ particles during solutionzing and $\theta$ particles during aging are formed from $\mathrm{Al}$ solution; however, it is not clear whether PFZs occur during solutionizing.

In this study, the microstructure and mechanical properties of three Al- $x \mathrm{wt} . \% \mathrm{Cu}-1.0$ wt.\% $\mathrm{Mn}$ alloys at ambient and elevated temperatures were investigated to find the precipitation behavior of $T_{\mathrm{Mn}}$ and $\mathrm{AlCu}_{3} \mathrm{Mn}_{2}$ phases in the $\mathrm{Al}-\mathrm{Cu}-\mathrm{Mn}$ system alloy and their contribution to the mechanical properties of the alloy.

\section{Experimental Procedures}

Three nominal Al- $x \mathrm{wt} . \% \mathrm{Cu}-1.0 \mathrm{Mn}$ alloys $(x=2.0,4.5$, and $7.5)$ were prepared by melting pure $\mathrm{Al}(99.7 \%)$ ingot and $\mathrm{Al}-20 \mathrm{Cu}$ and $\mathrm{Al}-10 \mathrm{Mn}$ master alloys in a resistance-heated furnace with the graphite crucible of $3 \mathrm{~kg}$ capacity. The prepared alloys are marked as $A_{1}, A_{2}$, and $A_{3}$, respectively, for 2, 4.5, and 7.5 wt. \% of $\mathrm{Cu}$ contents. MAX $\times \mathrm{LMF} 15$ spectrum was used to measure the chemical composition of the studied alloys, as listed in Table 1. After processing, the melts were poured into a metal mold with a cavity size of $170 \mathrm{~mm} \times 100 \mathrm{~mm} \times 20 \mathrm{~mm}$ which was preheated at $250^{\circ} \mathrm{C}$ for at least $5 \mathrm{~h}$.

Parts of the obtained castings underwent a heat treatment: solutionized at $525^{\circ} \mathrm{C}$ for $6 \mathrm{~h}+535^{\circ} \mathrm{C}$ for $6 \mathrm{~h}$ (a modified T6 state), followed by quenching in warm water and then aging at $170^{\circ} \mathrm{C}$ for $4 \mathrm{hrs}$. Metallography samples were cut from the castings. Optical microscope, SEM with GENESIS 60S X-ray EDS, and transmission electron
Table 1: Chemical composition of the studied alloys (wt.\%).

\begin{tabular}{lcccccc}
\hline Alloy & $\mathrm{Cu}$ & $\mathrm{Mn}$ & $\mathrm{Si}$ & $\mathrm{Mg}$ & $\mathrm{Fe}$ & $\mathrm{Al}$ \\
\hline $\mathrm{A}_{1}$ & 2.04 & 0.998 & 0.064 & 0.0009 & 0.130 & $\mathrm{Bal}$. \\
$\mathrm{A}_{2}$ & 4.54 & 0.917 & 0.059 & 0.0004 & 0.131 & $\mathrm{Bal}$. \\
$\mathrm{A}_{3}$ & 7.41 & 1.01 & 0.061 & 0.0006 & 0.138 & Bal. \\
\hline
\end{tabular}

microscopy (TEM) were applied to characterize the microstructure of as-cast, as-solutionized, and T6 samples. Tensile test samples (based on Chinese standard: GB/T2282002) were also cut from the castings with a gauge size of $35 \times 10 \times 3 \mathrm{~mm}^{3}$. The tensile testing was performed on a CMT4503 electronic universal testing machine with a rate of $1 \mathrm{~mm} / \mathrm{min}$ at $25^{\circ} \mathrm{C}$ and $300^{\circ} \mathrm{C}$. The data of mechanical properties are taken as an average of 3 samples.

\section{Results and Discussion}

3.1. Precipitation Behaviors during Solutionizing. Figure 1 shows the microstructure of the studied alloys assolutionized. At the first sight, it seems that these optical photos are not qualified. Actually, it is a great number of precipitates that lead to this fuzziness. High-magnification photo (Figure 1(d)) clearly exhibits the fine dispersoid particles precipitated during the solutionizing course of the Al-Cu-Mn alloys. Here, the area where precipitation particles exist is designated as the precipitation zone (PZ). Of more importance, this precipitation behavior is uneven. The contour of the primary dendrites of the $\alpha$-Al phase is dimly discernible, meaning that no or few particles are precipitated in the inner of dendrites (here, named as no particle zones, NPZs). It is seen that the area of NPZs is decreased with $\mathrm{Cu}$ content in the alloy, that is, the area of PZs is increased. And also there are a number of continuous or semicontinuous PFBs (precipitation-free bands) among the PZs. SEM image of the $\mathrm{A}_{2}$ alloy as-solutionized more powerfully illustrates this precipitation characteristic (Figure 2(a)). The EDS results (Figure 2(b)) suggest these precipitated particles contain high level of $\mathrm{Al}, \mathrm{Cu}$, and $\mathrm{Mn}$, being an $\mathrm{Al}-\mathrm{Cu}-\mathrm{Mn}$ compound. Figure 2 also shows a PFB (marked by Arrow 3) and $\mathrm{CuAl}_{2}$ particle that are survived from the solutionizing course.

Figure 3 shows the TEM images and EDS results of the precipitates in the studied alloys as-solutionized and SAD patterns of representative precipitation particles. TEM images exhibit that most of them take a shape of the rod, long or short in size, consistent with $[9-11,18]$. Usually, the composition detected by TEM-EDS is much more accurate than that by SEM-EDS. In the $\mathrm{A}_{1}$ alloy with a low $\mathrm{Cu}$ content of about 2 wt. $\%$, TEM-EDS result indicates the precipitation particles are $\mathrm{Al}-\mathrm{Cu}-\mathrm{Mn}$ compound with a $\mathrm{Cu} / \mathrm{Mn}$ atomic ratio close to $2: 3$ (Figure 3(b)). Feng et al. [9], Shen et al. [10], and Chen et al. [11] thought the rod-like particles precipitated in the solutionized $2 \times 24$ alloy and $\mathrm{Al}-5 \mathrm{Cu}-1 \mathrm{Mn}$ alloy are $T_{\mathrm{Mn}}$ phase with a formula of $\mathrm{Al}_{20} \mathrm{Cu}_{2} \mathrm{Mn}_{3}$. Liao et al. [18] also observed short rod-like dispersoid particles of the Al-Cu-Mn compound in the solutionized Al-Si-Cu-Mn alloy and identified it as $T_{\mathrm{Mn}}\left(\mathrm{Al}_{20} \mathrm{Cu}_{2} \mathrm{Mn}_{3}\right)$ by calculating the $\mathrm{SAD}$ patterns. According to the phase diagram of the Al-Cu-Mn system [19], 


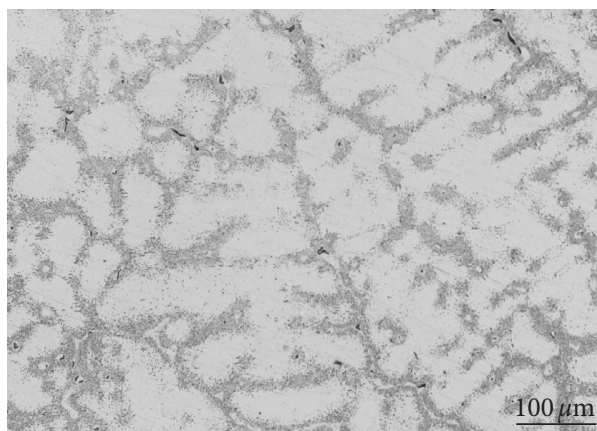

(a)

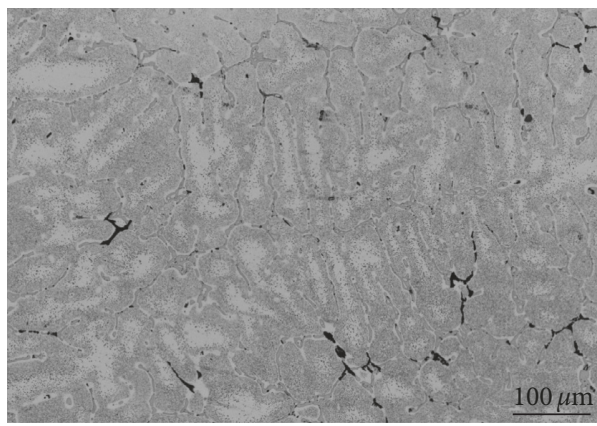

(c)

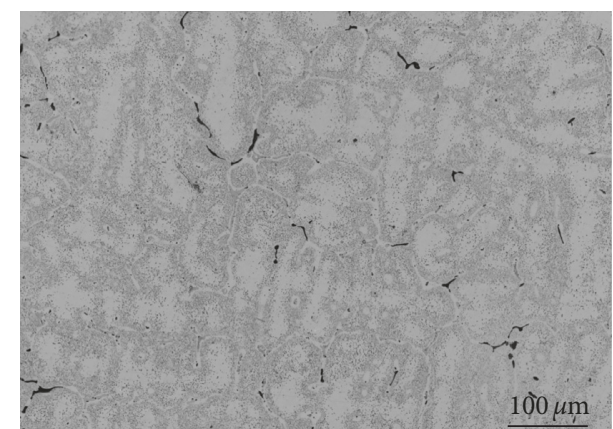

(b)

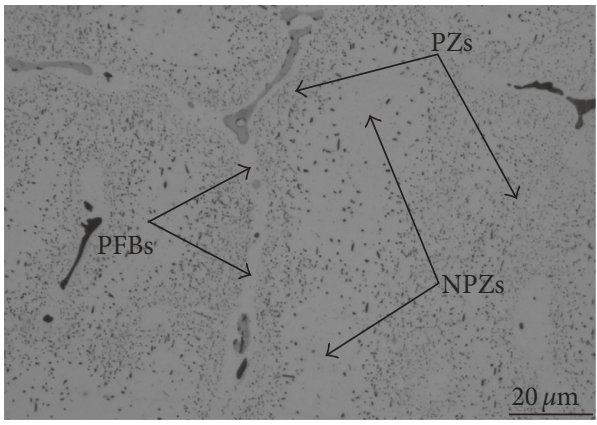

(d)

Figure 1: Optical microstructure of the studied alloys as-solutionized, showing PZs (precipitation zones), NPZs (no precipitation zones), and PFBs (precipitation-free bands): (a) $A_{1}$ alloy; (b) $A_{2}$ alloy; (c) $A_{3}$ alloy; (d) large magnification photo of the $A_{2}$ alloy.

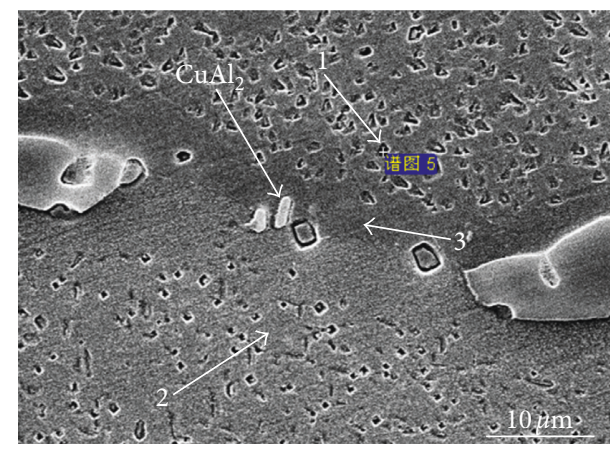

(a)

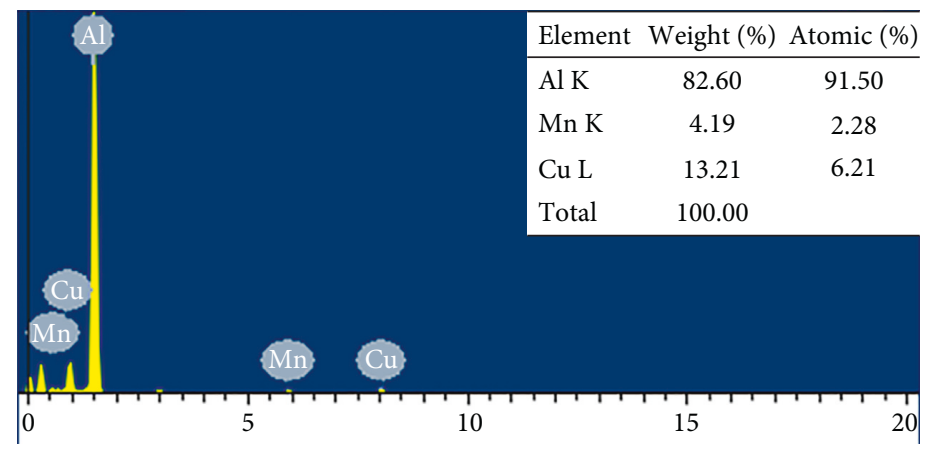

(b)

FIgURE 2: SEM image showing the precipitated particles (a) and its EDS results marked by Arrow 1 (b) in the $A_{2}$ alloy as-solutionized

in the $\mathrm{Cu}$-rich corner, the most possible phase of $\mathrm{Al}-\mathrm{Cu}-\mathrm{Mn}$ compounds is $T_{\mathrm{Mn}}$. Thus, the precipitates in the $\mathrm{A}_{1}$ alloy are thought to be the $T_{\mathrm{Mn}}$ phase. Calculation of the SAD pattern in Figure 3(c) further demonstrates it, having an orthorhombic structure with lattice parameters $a=2.420 \mathrm{~nm}$, $b=1.250 \mathrm{~nm}$, and $c=0.772 \mathrm{~nm}$ that is consistent with Wang's et al. [13] and Park and Kim's [14] models. But $\mathrm{A}_{2}$ and $\mathrm{A}_{3}$ alloys with high $\mathrm{Cu}$ content are about 4.5 wt.\% and $7.0 \mathrm{wt} . \%$, respectively, besides $T_{\mathrm{Mn}}$ precipitates (such as Arrow 2 in Figure 3(e) and EDS in Figure 3(f) and Arrow 4 in Figure 3(i) and EDS in Figure 3(j)), and another Al-Cu-Mn precipitation particles are found (such as Arrow 1 in Figure 3(e) and Arrow 3 in Figure 3(i)), in which the EDS results (Figures 3(d) and $3(\mathrm{~h})$ ) indicate they have an almost same $\mathrm{Cu} / \mathrm{Mn}$ atomic ratio of $3: 2$. In 1968, Johnston and Hall [15] identified the crystal structure of the $\mathrm{Cu}_{3} \mathrm{Mn}_{2} \mathrm{Al}$ compound in its singlephase system by X-ray and neutron diffractometer traces: it is a cubic Laves phase with the 8 manganese atoms ordered at the geometrically larger A sites, while the copper and aluminum atoms are randomized in the 16-fold $B$ sites, and its parameter is $6.9046 \AA$. In this study, the calculation of the SAD pattern of this compound (Figure $3(\mathrm{~g})$ ) suggests that it has a simple cubic structure with $a=0.6904 \mathrm{~nm}$, equal to $\mathrm{AlCu}_{3} \mathrm{Mn}_{2}$ (PDF card no.: 23-0760). Thus, these $\mathrm{Al}-\mathrm{Cu}-\mathrm{Mn}$ precipitation particles with a $\mathrm{Cu} / \mathrm{Mn}$ atomic ratio of $3: 2$ found in the as-solutionized $A_{2}$ and $A_{3}$ alloys are identified as $\mathrm{AlCu}_{3} \mathrm{Mn}_{2}$. Now, it is concluded that, in the $\mathrm{Al}-\mathrm{Cu}-\mathrm{Mn}$ alloy with a low $\mathrm{Cu}$ content, there are only $T_{\mathrm{Mn}}\left(\mathrm{Al}_{20} \mathrm{Cu}_{2} \mathrm{Mn}_{3}\right)$ dispersoid particles precipitated during the solutionizing course, but in the alloy with a high $\mathrm{Cu}$ 


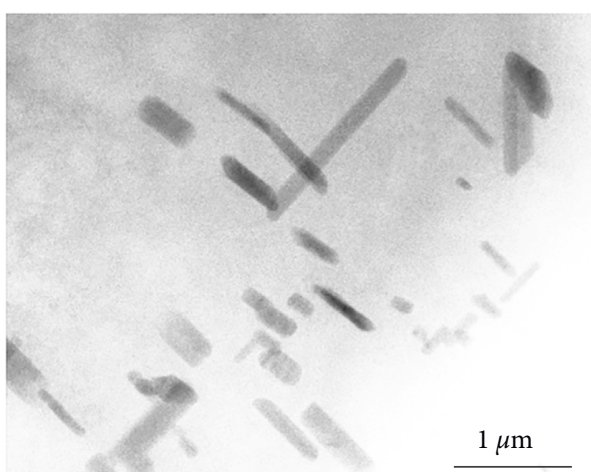

(a)

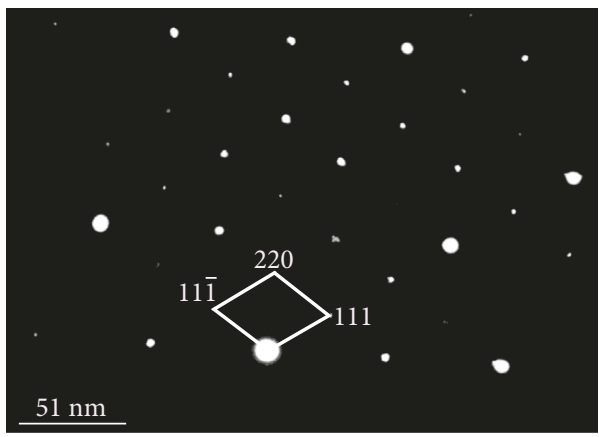

(c)

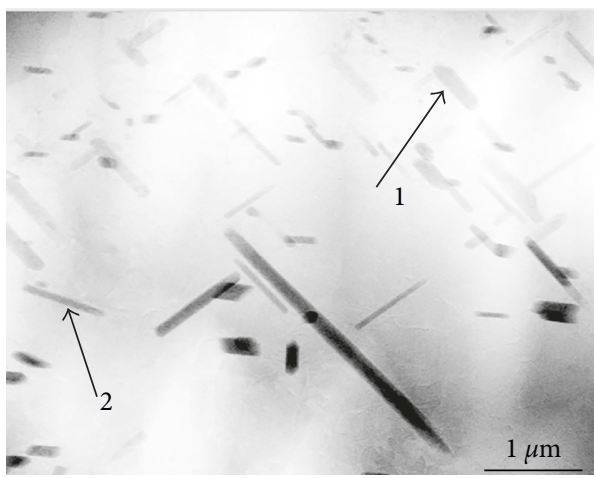

(e)

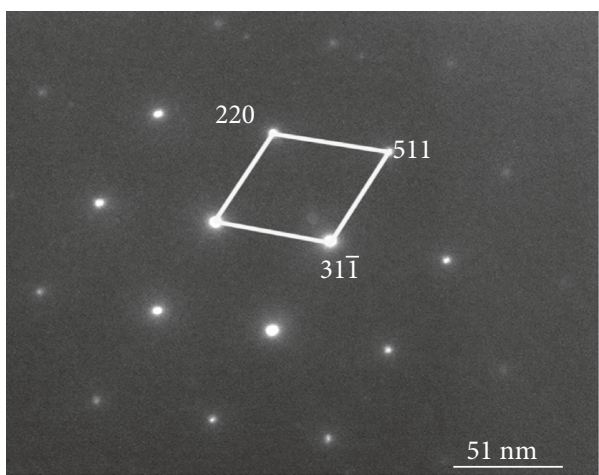

(g)

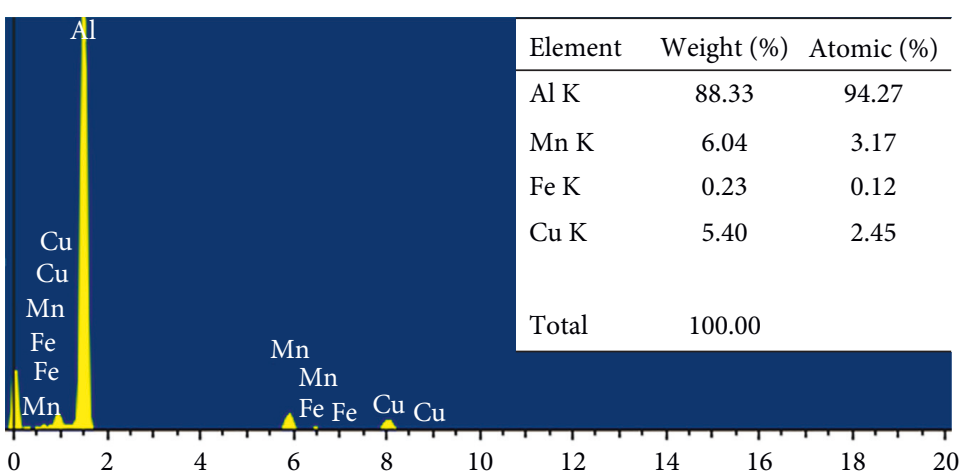

(b)

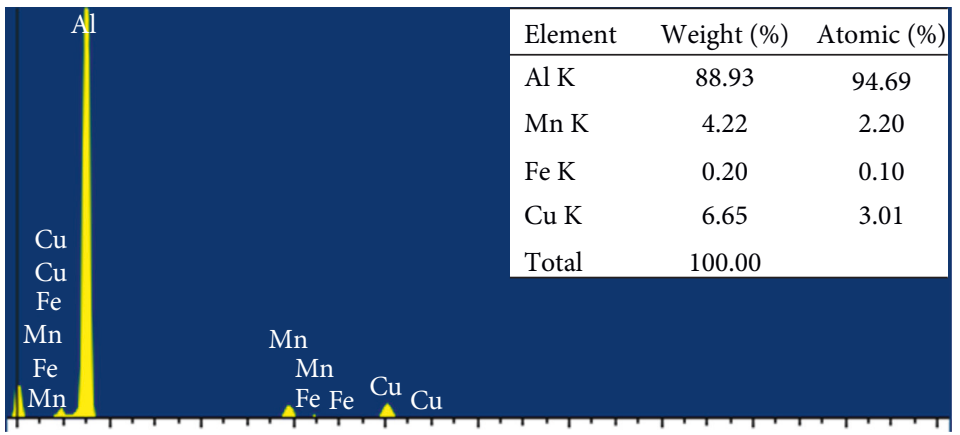

(d)

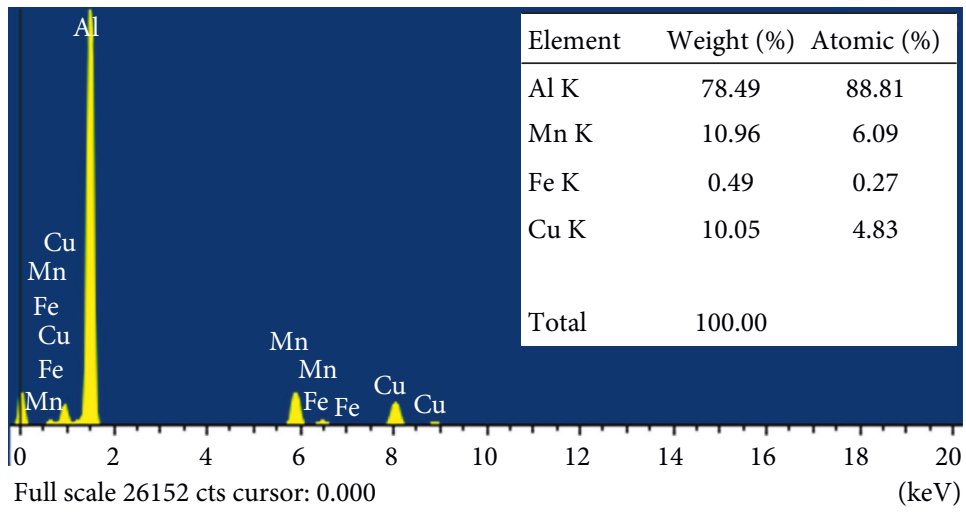

(f)

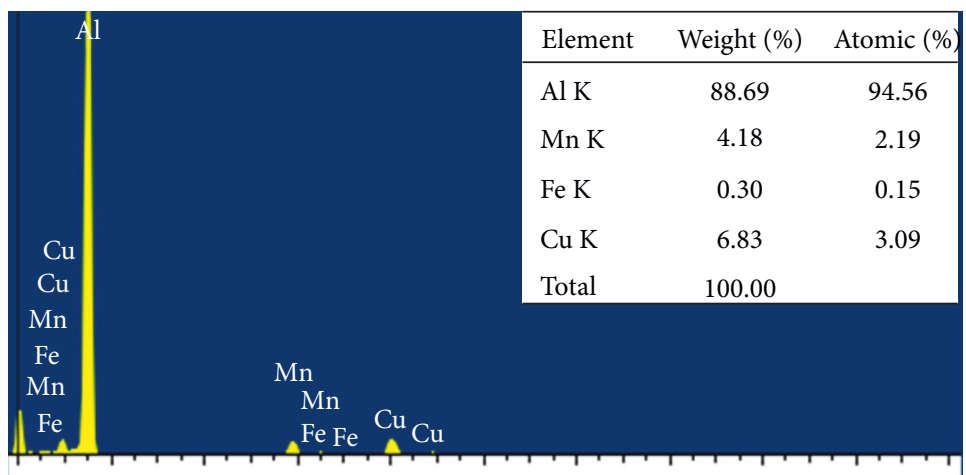

Figure 3: Continued. 


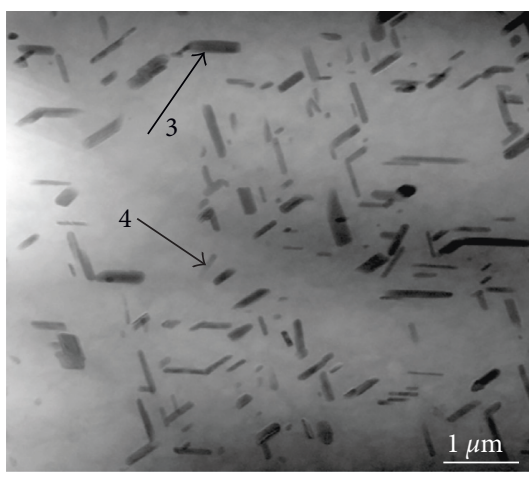

(i)

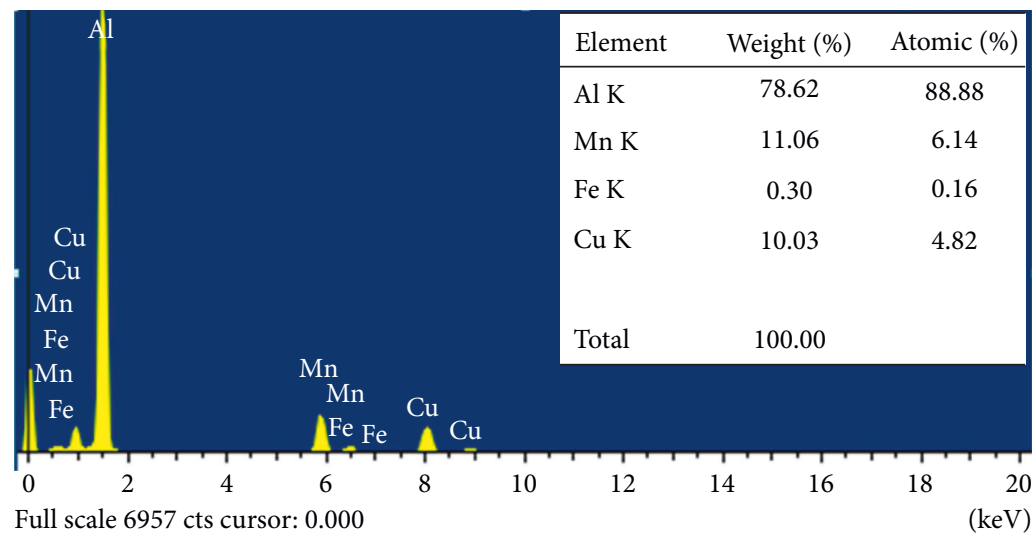

(j)

FIGURE 3: Transmission electron micrographs of precipitated particles in $A_{1}(a), A_{2}(e)$, and $A_{3}$ (i) alloys as-solutionized; representative EDS (b) and SAD (c) results of the $T_{\mathrm{Mn}}$ phase in the A1 alloy; EDS (d) and SAD (g) results of the $\mathrm{AlCu}_{3} \mathrm{Mn}_{2}$ phase and EDS (f) of the $T_{\mathrm{Mn}}$ phase in the A2 alloy, respectively, marked by Arrows 1 and 2 in (e); EDS results ( $\mathrm{h}, \mathrm{j}$ ) of the particles $\mathrm{AlCu}_{3} \mathrm{Mn}_{2}$ and $T_{\mathrm{Mn}}$ in the A3 alloy, respectively, marked by Arrows 3 and 4 in (i)

content, $\mathrm{AlCu}_{3} \mathrm{Mn}_{2}$ particles are demonstrated to precipitate beside $T_{M n}$ particles. From Figure 3, it is also worth to note that the number of precipitation particles is increased with $\mathrm{Cu}$ content in the alloys; however, the particle size is decreased simultaneously, which will exert impact to the tension properties.

To deeply understand this precipitation behavior during solutionizing, uneven precipitation of the $T_{\mathrm{Mn}}$ phase, and formation of PFBs among the PZs, it is necessary to carefully characterize the microstructure as-cast. Figure 4 shows the optical microstructure of the $A_{1}, A_{2}$, and $A_{3}$ alloys as-cast. There are particulate-like or continuous/semicontinuous network constitutes in the interdendritic area. They are eutectic resultants during the final stages of nonequilibrium solidification of the Al-Cu-Mn alloy: $L \rightarrow \alpha-\mathrm{Al}+\theta$ and $L \rightarrow \alpha-\mathrm{Al}+\theta+T_{\mathrm{Mn}}[19-21]$. SEM images of three constitute and their EDS results in Figure 5 demonstrate it. With $\mathrm{Cu}$ content in the alloy, the amount of network $\theta$ phase is increased in the eutectic resultants (Figure 5).

It is very interesting to note that, in Figure 4, there are two contrasts on primary $\alpha$-Al dendrites, like a shell-core structure. The part in the core of dendrites is partly bright, and the shell around the core is partly grey. In SEM image (Figure 6(a)), the core of dendrites presents as dark-grey and the shell as light-grey. EDS results of two regions are illustrated in Figures 6(b) and 6(c), respectively, suggesting that $\mathrm{Cu}$ content in the shell is much higher than that in the core; however, Mn content is almost equal. EPMA diagrams in Figure 7 show the distribution of $\mathrm{Cu}, \mathrm{Fe}$, and $\mathrm{Mn}$ elements in the microstructure of the $\mathrm{A}_{2}$ alloy as-cast. It demonstrates again that the shell of dendrites is much more $\mathrm{Cu}$-rich than the core. And except for a few regions with the $T_{\mathrm{Mn}}$ phase, the other regions where $\mathrm{CuAl}_{2}$ phase exists alone are highly $\mathrm{Mn}$-poor. Now, the shell region of $\alpha$-Al dendrites can be denoted as the $\mathrm{Cu}$-rich region. The Al-rich corner of the $\mathrm{Al}-\mathrm{Cu}-\mathrm{Mn}$ phase diagram is rather complicated [19]. The physic process for the formation of this obvious shell-core structure of primary $\alpha-\mathrm{Al}$ dendrites is still unknown.
Of more importance, the area of $\mathrm{Cu}$-rich regions is increased with $\mathrm{Cu}$ content in the alloy (Figure 4). Carefully comparing Figure 1 with Figure 4, it is found in surprise that $\mathrm{Cu}$-rich regions in as-cast microstructure are highly consistent with the precipitation zones in as-solutionized microstructure. It is just in the $\mathrm{Cu}$-rich regions that precipitation of $T_{\mathrm{Mn}}$ and $\mathrm{AlCu}_{3} \mathrm{Mn}_{2}$ dispersoid particles occurs. Due to nonequilibrium solidification, a shell-core structure of primary $\alpha$ - $\mathrm{Al}$ dendrites is formed. In $\mathrm{Cu}$-rich regions, $\mathrm{Cu}$ content is about $5 \mathrm{wt} . \%$ (Figure 6(c)), very close to the maximum solubility of $\mathrm{Cu}$ solute in $\mathrm{Al}$ solution in the $\mathrm{Al}-\mathrm{Cu}$ binary system. In other words, these $\mathrm{Cu}$-rich regions are supersaturated actually. In the course of solutionizing at $525^{\circ} \mathrm{C}$ for $6 \mathrm{hrs}+535^{\circ} \mathrm{C}$ for $6 \mathrm{hrs}$, part of the eutectic $\mathrm{CuAl}_{2}$ phase formed during nonequilibrium solidification is forced to redissolve into the $\mathrm{Al}$ matrix. In the $\mathrm{A} 1$ alloy with only 2 wt.\% $\mathrm{Cu}$ content, the eutectic $\mathrm{CuAl}_{2}$ phase is dissolved completely (Figure 8(a)); however, in the $\mathrm{A}_{2}$ and $\mathrm{A}_{3}$ alloys, there are some eutectic $\mathrm{CuAl}_{2}$ particles which survived (Figures $8(\mathrm{~b})$ and $8(\mathrm{c})$, resp.). Eutectic $\mathrm{CuAl}_{2}$ phase is located in the $\mathrm{Cu}$-rich regions (Figure 4). The redissolution of these regions further enhances the degree of supersaturation. Even at $535^{\circ} \mathrm{C}$ of solutionizing temperature, it is supersaturated. Thus, it is the supersaturation of the $\mathrm{Cu}$ solute in the $\mathrm{Al}$ solution that drives the precipitation of $T_{\mathrm{Mn}}$ and $\mathrm{AlCu}_{3} \mathrm{Mn}_{2}$ to occur in the $\mathrm{Cu}$-rich regions. Because the diffusion coefficient of manganese in the $\mathrm{Al}$ solution is very low $\left(1 \times 10^{-12} \cdot \mathrm{cm}^{2} / \mathrm{s}\right)$, much less than that of copper $\left(5 \times 10^{-9} \cdot \mathrm{m}^{2} / \mathrm{s}\right)$ [22], the precipitated particles of $T_{\mathrm{Mn}}$ and $\mathrm{AlCu}_{3} \mathrm{Mn}_{2}$ phase are fine and dispersed. With $\mathrm{Cu}$ content in the alloy, the area of the $\mathrm{Cu}$-rich regions is increased, and hence, the area of PZs is also increased. In the alloy with high $\mathrm{Cu}$ content, the degree of supersaturation becomes larger, and thus, the driving force for precipitation becomes stronger that leads to an increase in amount and a decrease in size of the precipitated particles. But in the core part of dendrites, the $\mathrm{Cu}$ solute is much poor, so no precipitation occurs, forming NPZs in the original core parts of dendrites. 


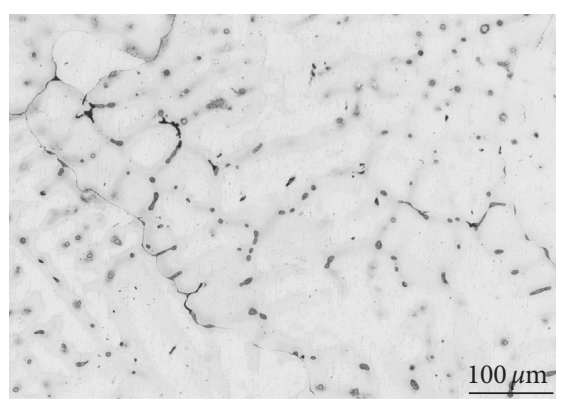

(a)

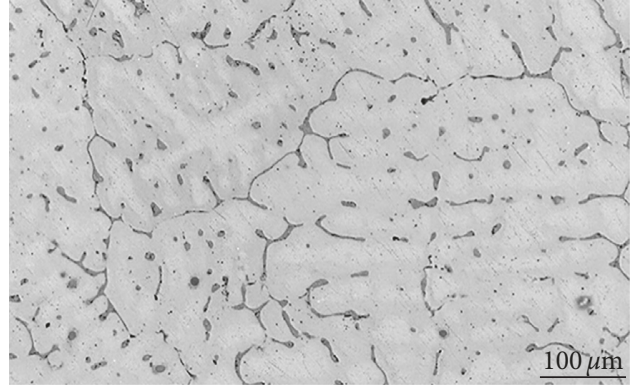

(b)

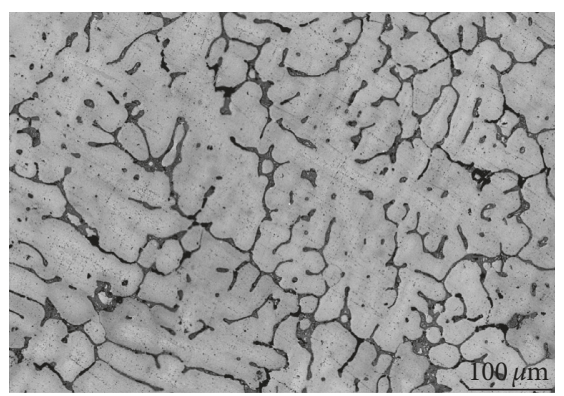

(c)

Figure 4: Optical microstructures of three Al-Cu-Mn alloys as-cast: (a) $A_{1}$ alloy; (b) $A_{2}$ alloy; (c) $A_{3}$ alloy.

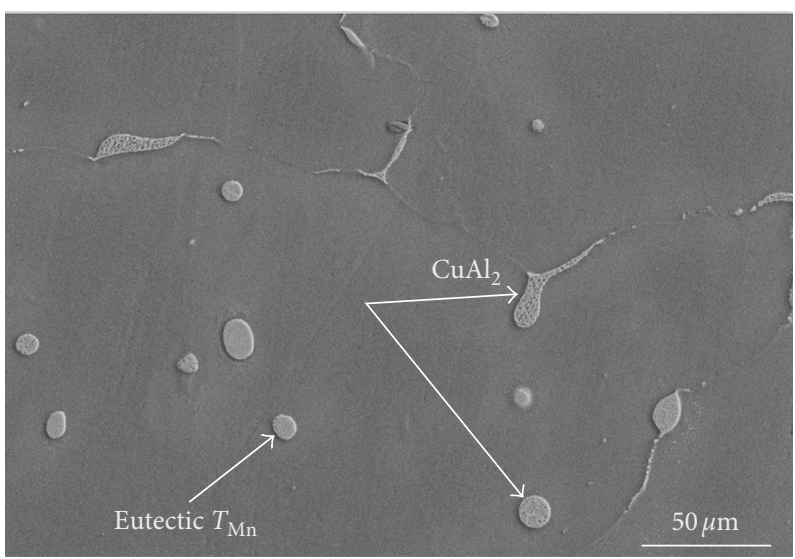

(a)

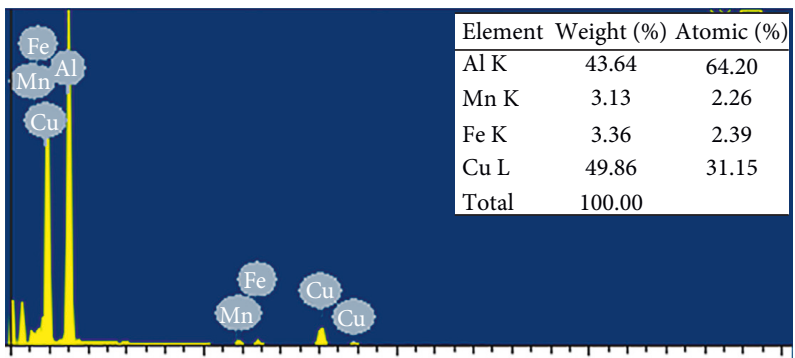

(c)

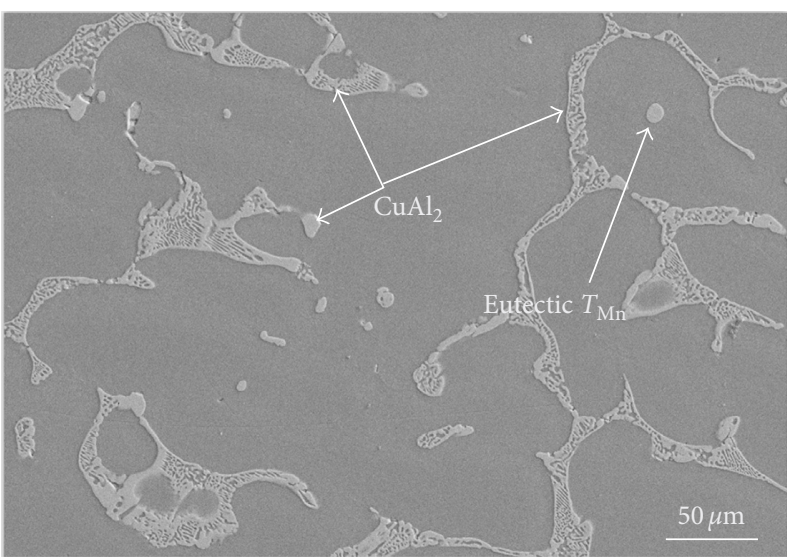

(b)

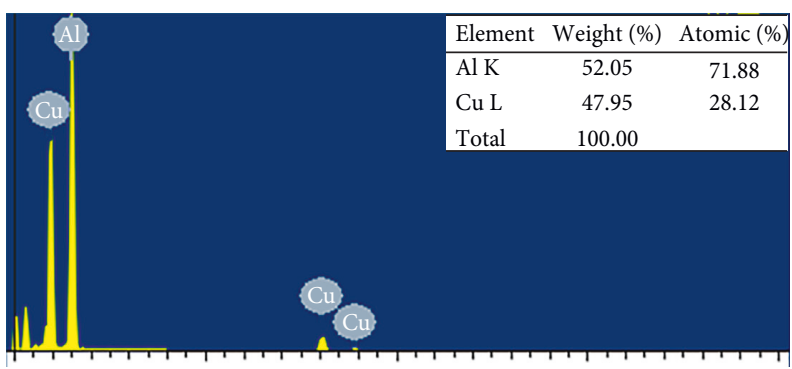

(d)

Figure 5: Continued. 


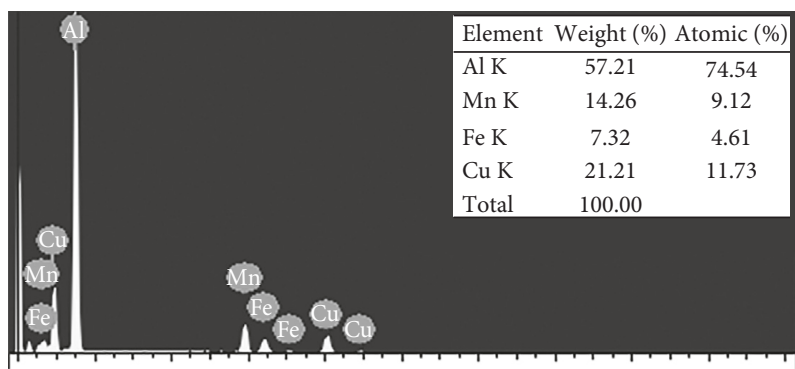

(e)

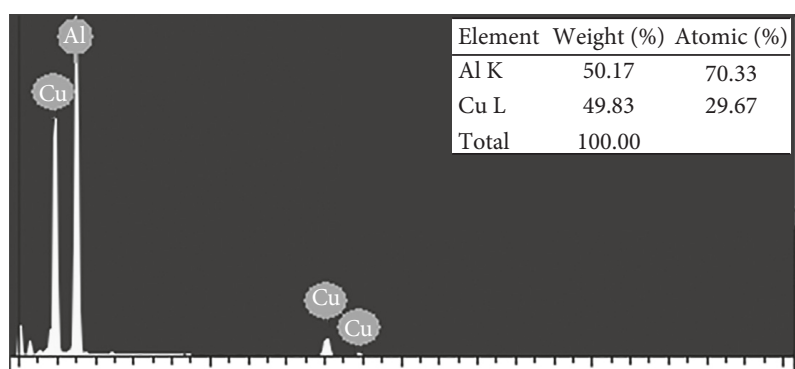

(f)

Figure 5: SEM images of Al-Cu-Mn alloys as-cast: (a) $A_{1}$ alloy; (b) $A_{3}$ alloy; (c, d) EDS results of the $T_{M n}$ and $\theta$ phases in the $A_{1}$ alloy, respectively; (e, f) EDS results of the $T_{\mathrm{Mn}}$ and $\theta$ phases in the $\mathrm{A}_{3}$ alloy, respectively.

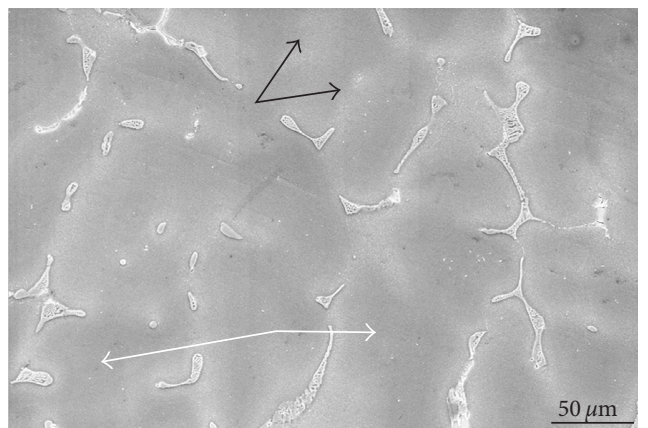

(a)

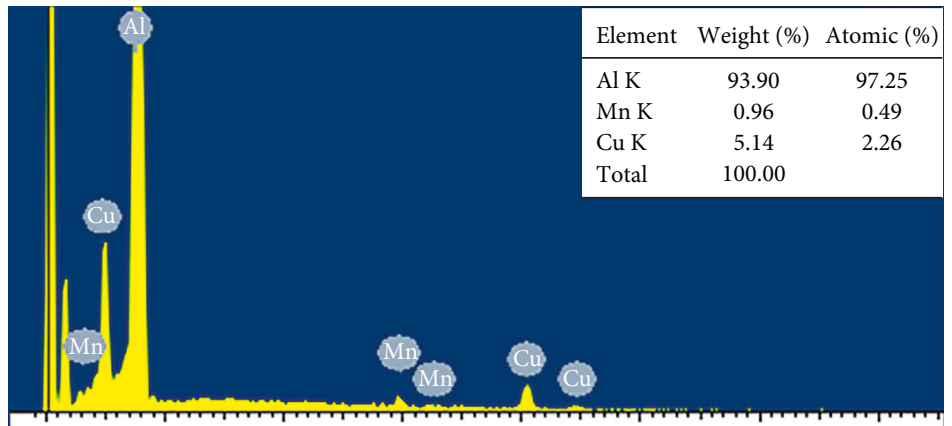

(b)

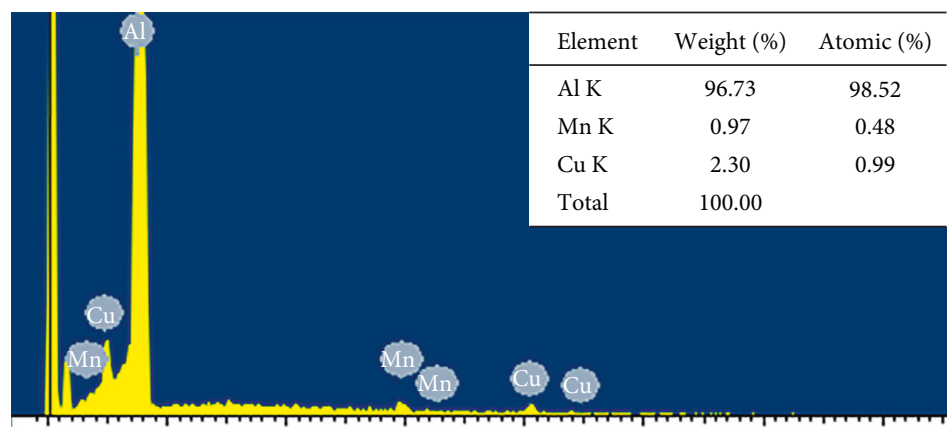

(c)

FIGURE 6: SEM image showing the light-grey and dark-grey areas of dendrites in the $\mathrm{A}_{2}$ alloy as-cast (a) and the EDS results of the light-grey area (b) and dark-grey area (c).

As seen in Figure 1, a number of PFBs are formed, and it becomes more apparent with $\mathrm{Cu}$ content in the alloy. Figure 2 more clearly exhibits a PFB between PZs, marked by Arrow 3. In the PFB, there are some $\mathrm{CuAl}_{2}$ particles which survived.
Arrow 2 in Figure 2 presents the blank region in PZs. Figure 9 illustrates the EDS results of the regions denoted by Arrows 2 and 3. In the blank region in PZs, the content of $\mathrm{Mn}$ is still high to about $0.7 \mathrm{wt} . \%$, and even $T_{\mathrm{Mn}}$ and $\mathrm{AlCu}_{3} \mathrm{Mn}_{2}$ particles have 

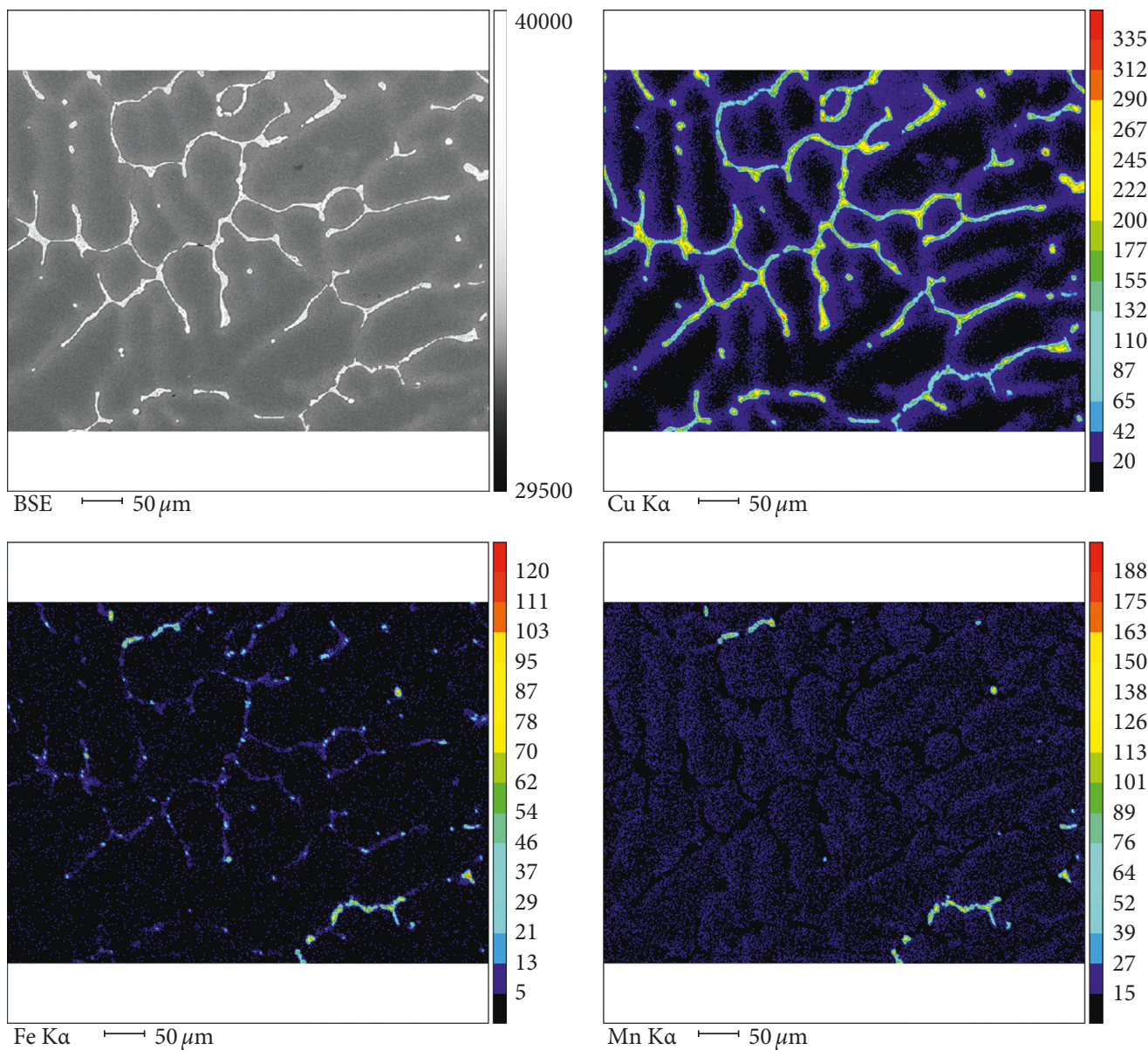

Figure 7: EPMA microstructure in the $\mathrm{A}_{2}$ alloy as-cast, showing the distribution of solute elements of $\mathrm{Cu}, \mathrm{Fe}$, and $\mathrm{Mn}$ (for interpretation of the references to color in this figure legend, the reader is referred to the web version of this article).

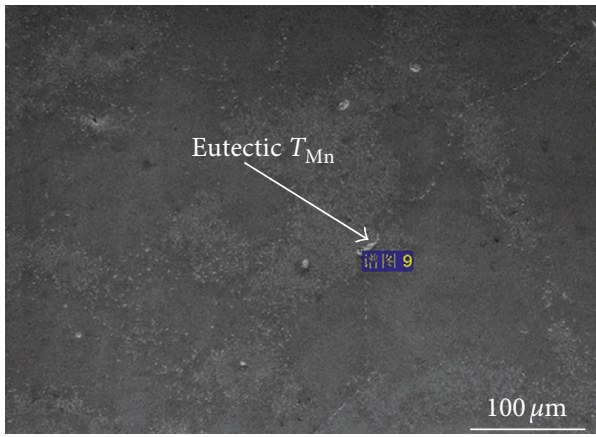

(a)

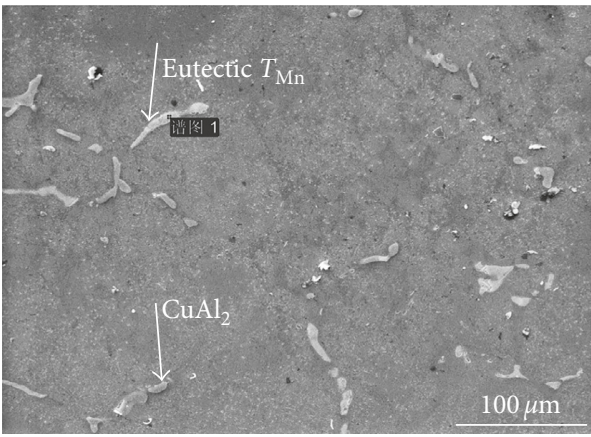

(b)

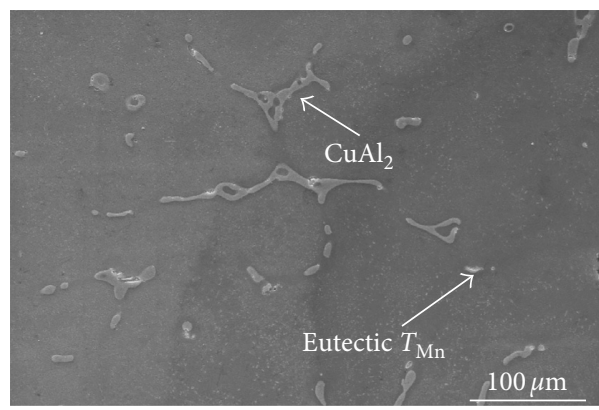

(c)

Figure 8: SEM images showing the variation of eutectic phases after solution treatment: (a) $A_{1}$ alloy; (b) $A_{2}$ alloy; (c) $A_{3}$ alloy. 


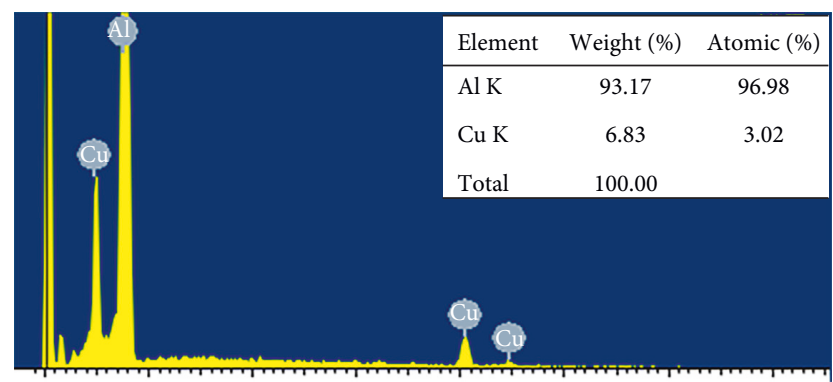

(a)

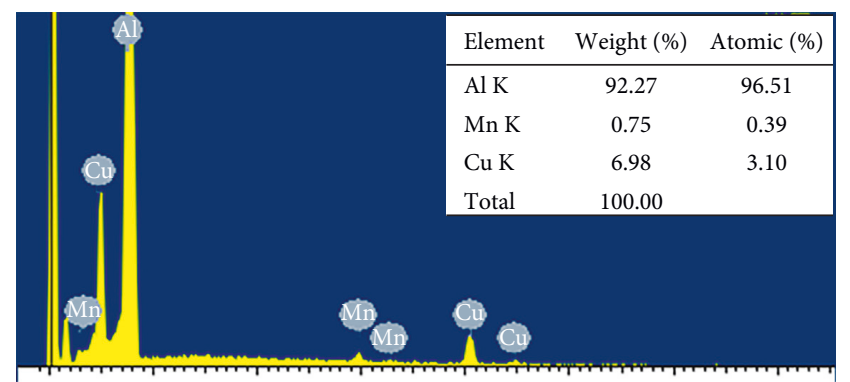

(b)

Figure 9: EDS results of the regions marked by Arrow 2 (a) and Arrow 3 (b) in Figure 2(a).

precipitated around it, but in the PFB, no Mn trace is detected. Figure 7 illustrates that the regions where the $\mathrm{CuAl}_{2}$ phase exists alone are highly $\mathrm{Mn}$-poor. With $\mathrm{Cu}$ content in the alloy, the amount of the eutectic $\mathrm{CuAl}_{2}$ phase formed in form of nonequilibrium is increased (as seen in Figures 4 and 5). During the course of solutionizing at $525^{\circ} \mathrm{C}$ for $6 \mathrm{hrs}+535^{\circ} \mathrm{C}$ for $6 \mathrm{hrs}$, first, this eutectic $\mathrm{CuAl}_{2}$ phase in form of nonequilibrium has to be redissolved into matrix, and then, the remaining $\mathrm{CuAl}_{2}$ phase becomes granulated. This evolution of redissolution and granulation of the eutectic $\mathrm{CuAl}_{2}$ phase leaves the band area where it is highly $\mathrm{Mn}$-poor. It is due to $\mathrm{Mn}$-poor that no precipitation of $T_{\mathrm{Mn}}$ and $\mathrm{AlCu}_{3} \mathrm{Mn}_{2}$ particles takes place there, and thus, PFBs are formed among the PZs. In the alloy with higher $\mathrm{Cu}$ content, the amount of the eutectic $\mathrm{CuAl}_{2}$ phase that would be dissolved is increased, and thus, the formed PFBs become more apparent. It is concluded that it is the redissolution and granulation of the eutectic $\mathrm{CuAl}_{2}$ phase that lead to the formation of PFBs between PZs.

3.2. Contribution to Tension Properties. For the $\mathrm{A}_{2}$ alloy, the tension mechanical properties at different states are as follows: as-cast, as-solutionized, and T6 that are labeled in Table 2. In case of the tension test at room temperature $\left(25^{\circ} \mathrm{C}\right)$, solutionizing treatment results in a remarkable increase in both the UTS (ultimate tension strength) and YS (yield strength) by $74.1 \%$ and $74.4 \%$, respectively, without sacrificing the elongation, and further aging treatment also considerably increases the UTS (from $256 \mathrm{MPa}$ to $369 \mathrm{MPa}$ ), YS (from $157 \mathrm{MPa}$ to $248 \mathrm{MPa}$ ), and elongation (from $4.8 \%$ to $6.3 \%$ ) again. But, under the tension test at $300^{\circ} \mathrm{C}$, the case is different. Solutionizing treatment produces an appreciable increase in UTS and YS by $29.2 \%$ and $36.8 \%$, respectively; however, further aging treatment does not lead to obvious improvement of strength both in YS and UTS. Engineering stress verses strain curves shown in Figure 10 vividly exhibit the contribution of microstructure evolution to mechanical properties. The curves of tension at room temperature in Figure 10(a) are common as expected. Both the microstructure evolutions occurring during the solutionizing and aging courses contribute to their respective strengthening effects. Curves in Figure 10(b) reveal the physic process in strengthening at high temperature. In case of tension at $300^{\circ} \mathrm{C}$, for the sample as-cast, hardening occurs with further
TABle 2: Tension properties at $25^{\circ} \mathrm{C}$ and $300^{\circ} \mathrm{C}$ of the $\mathrm{A}_{2}$ alloy at different states.

\begin{tabular}{lcccc}
\hline State & & UTS $(\mathrm{MPa})$ & YS $(\mathrm{MPa})$ & Elongation (\%) \\
\hline \multirow{2}{*}{ As-cast } & $25^{\circ} \mathrm{C}$ & $147 \pm 9.0$ & $90 \pm 4.0$ & $4.5 \pm 0.7$ \\
& $300^{\circ} \mathrm{C}$ & $89 \pm 8.0$ & $68 \pm 5.0$ & $6 \pm 0.5$ \\
\hline \multirow{2}{*}{ As- } & $25^{\circ} \mathrm{C}$ & $256 \pm 18.0$ & $157 \pm 1.6$ & $4.8 \pm 0.7$ \\
solutionized & $300^{\circ} \mathrm{C}$ & $115 \pm 6.0$ & $93 \pm 2.6$ & $6.04 \pm 2.1$ \\
\hline \multirow{2}{*}{ T6 } & $25^{\circ} \mathrm{C}$ & $369 \pm 22.0$ & $248 \pm 4.5$ & $6.26 \pm 0.8$ \\
& $300^{\circ} \mathrm{C}$ & $116 \pm 11.0$ & $96 \pm 8.0$ & $8.3 \pm 4.5$ \\
\hline
\end{tabular}

plastic deformation beyond yielding, but it merely sustains for only about $4 \%$ strain in total, and then a collapse failure arrives suddenly. For samples as-solutionized and T6 tempered, the curves of the two samples are almost the same at the first half stage, with almost equal values both in UTS and YS. Surely, the values are much higher than that as-cast. And the hardening behavior also occurs with further plastic deformation beyond yielding. However, after the hardening reaches a maximum at about $4 \mathrm{w} . \%$ strain in total, slightly softening occurs. It continues to a much larger strain of about $8 \%$ and $10 \%$ in total, respectively, until the final collapse failure. This softening is from dynamic recovery or recrystallization during plastic deformation with a slow strain rate (about $0.0033 \mathrm{~s}^{-1}$ ) at high temperature, which needs more attention. Compared with the sample as-cast, what support does the samples get (as-solutionized and T6) to tolerate much larger plastic deformation? In the $\mathrm{A}_{2}$ alloy as-cast, the microstructure is constituted with the dendritic $\alpha$-Al phase and small amount of the eutectic $T_{\mathrm{Mn}}$ and $\theta$ phases. After solutionizing, a great number of fine $T_{\mathrm{Mn}}$ and $\mathrm{AlCu}_{3} \mathrm{Mn}_{2}$ dispersoid particles are precipitated in the $\mathrm{A}_{2}$ alloy except for the redissolving of part of the eutectic $\theta$ phase (Figures 1-3 and 8). Once these $T_{M n}$ and $\mathrm{AlCu}_{3} \mathrm{Mn}_{2}$ particles are formed during the solutionizing course, they will almost not change whether in morphology or in size even when they undergo another thermal history with a temperature less than the solutionizing temperature. It is due to its complicated structure and much low diffusion coefficient of $\mathrm{Mn}$ in the $\mathrm{Al}$ solution [12, 18, 23]. In the sample after aging treatment, the needle-like $\theta^{\prime \prime}$ and slender rod-like $\theta^{\prime}$ phases in the conventional Al-Cu alloy have not been observed. Conversely, a number of very fine particles (dozens of nanometers in size) are found to precipitate on the rod-like $T_{\mathrm{Mn}}$ particles, as shown in 


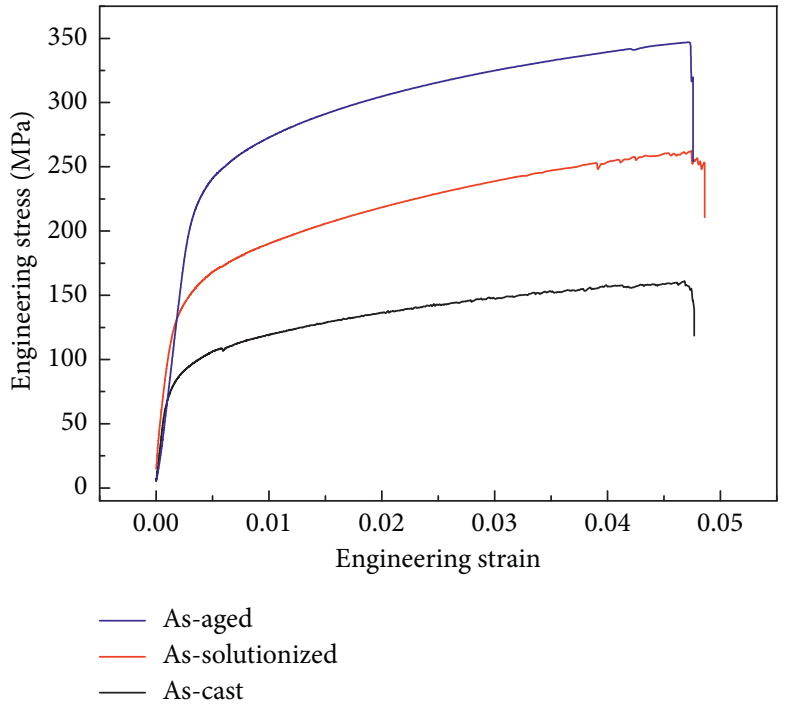

(a)

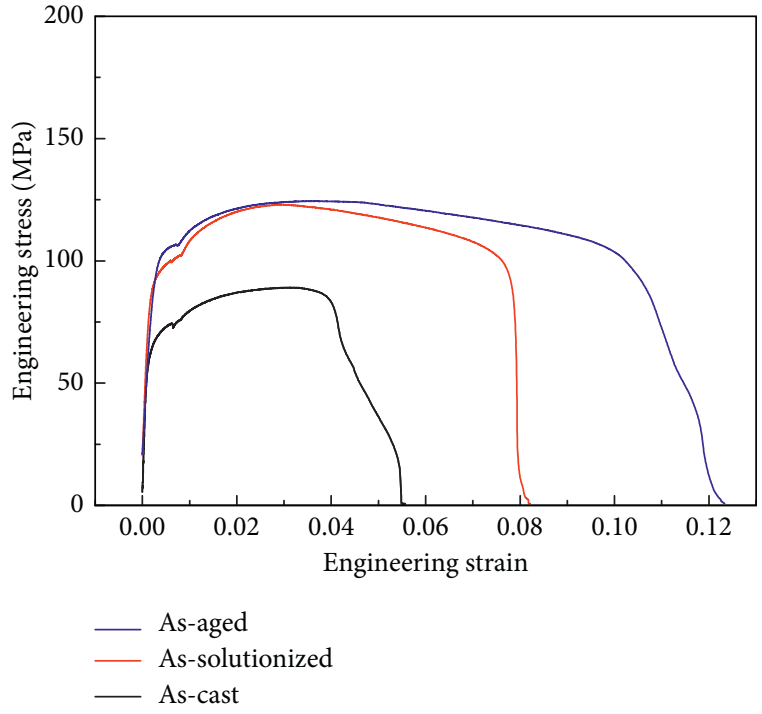

(b)

Figure 10: Typical engineering stress-strain curves of the $\mathrm{A}_{2}$ alloy at different states: (a) tension at room temperature; (b) tension at $300^{\circ} \mathrm{C}$.

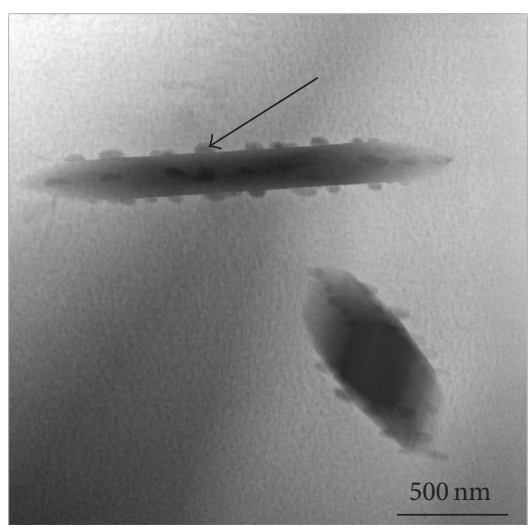

(a)

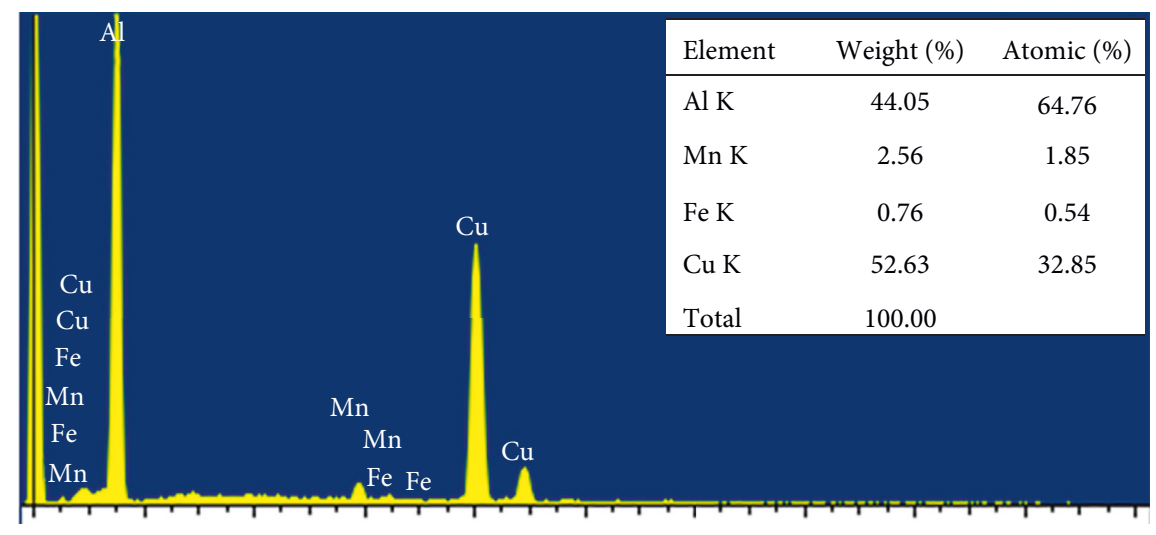

(b)

Figure 11: TEM image showing very fine precipitation particles around/on the rod-like $T_{\mathrm{Mn}}$ particles in the $\mathrm{A}_{2}$ alloy $\mathrm{T} 6$ tempered (a) and its EDS results (b).

Figure 11(a). Its EDS results (Figure 11(b)) indicate that it contains a large amount of $\mathrm{Cu}$ and $\mathrm{Al}$ and a small amount of $\mathrm{Mn}$ and $\mathrm{Fe}$. However, due to its $\mathrm{Cu} / \mathrm{Al}$ atom ratio close to $1: 2$, these fine precipitates may be the metastable $\theta$ phase. The precipitation behavior of these fine particles during aging may be responsible for the considerable increment in room temperature strength of the T6 samples compared with the as-solutionized samples. These particles precipitated during the aging course can strengthen the matrix in case of tension at room temperature. But usually, these particles formed during aging possess simple structure, and the diffusion coefficient of the constituents is high, such as $\mathrm{Cu}, \mathrm{Si}$, and $\mathrm{Mg}$ in the $\mathrm{Al}$ solution, and thus, these particles will be coarsened quickly even redissolved when they undergo another thermal history [24-27]. So, the particles of the $\mathrm{Al}-\mathrm{Cu}-\mathrm{Mn}$ phases and metastable $\theta$ phase precipitated during the solutionizing and aging courses, respectively, remarkably increase the YS and UTS at room temperature (Figure 10(a) and Table 2). But the microstructure evolution occurring in the aging course does not lead to an improvement in YS and UTS at $300^{\circ} \mathrm{C}$ (Table 2 and Figure 10(b)). It is a great number of $T_{\mathrm{Mn}}$ and $\mathrm{AlC}$ $\mathrm{u}_{3} \mathrm{Mn}_{2}$ particles precipitated during solutionizing that support the samples (as-solutionized and T6) to tolerate much larger plastic deformation. That is, the considerable increments in YS and UTS at $300^{\circ} \mathrm{C}$ of the $\mathrm{A}_{2}$ alloy assolutionized and T6 tempered are almost completely contributed to the dispersoid precipitation of a great number of $T_{\mathrm{Mn}}$ and $\mathrm{AlCu}_{3} \mathrm{Mn}_{2}$ particles. Meanwhile, it also indicates that the precipitation behavior in the aging course has no or little contribution to high temperature strength. On other words, if a component is working at a low temperature or room temperature, aging treatment is necessary. And if it is at high temperature, such as at/above $300^{\circ} \mathrm{C}$, solutionizing treatment is enough, and aging treatment is completely unnecessary. 
TABle 3: Tension properties at $25^{\circ} \mathrm{C}$ and $300^{\circ} \mathrm{C}$ of the studied alloys T6 tempered.

\begin{tabular}{lcccc}
\hline Alloy & & UTS (MPa) & YS (MPa) & Elongation (\%) \\
\hline \multirow{2}{*}{$\mathrm{A}_{1}$} & $25^{\circ} \mathrm{C}$ & $153 \pm 4.0$ & $66 \pm 2.0$ & $8.4 \pm 1.7$ \\
& $300^{\circ} \mathrm{C}$ & $53 \pm 3.3$ & $44 \pm 2.9$ & $11 \pm 6.0$ \\
\hline \multirow{2}{*}{$\mathrm{A}_{2}$} & $25^{\circ} \mathrm{C}$ & $369 \pm 22.0$ & $248 \pm 4.5$ & $6.26 \pm 0.8$ \\
& $300^{\circ} \mathrm{C}$ & $116 \pm 11.0$ & $96 \pm 11.0$ & $8.3 \pm 4.5$ \\
\hline \multirow{2}{*}{$\mathrm{A}_{3}$} & $25^{\circ} \mathrm{C}$ & $323 \pm 8.0$ & $303 \pm 3.0$ & $1.08 \pm 0.28$ \\
& $300^{\circ} \mathrm{C}$ & $134 \pm 5.4$ & $101 \pm 4.5$ & $10 \pm 3.6$ \\
\hline
\end{tabular}

The tension mechanical properties at $25^{\circ} \mathrm{C}$ and $300^{\circ} \mathrm{C}$ of the studied alloys after T6 treatment are listed in Table 3. In case of tension at $25^{\circ} \mathrm{C}$, the YS is increased significantly from $66 \mathrm{MPa}$ to $303 \mathrm{MPa}$ with $\mathrm{Cu}$ content in the alloy changing from $2.0 \mathrm{wt} . \%$ to $7.5 \mathrm{wt} . \%$. But for UTS, the $\mathrm{A}_{2}$ alloy has the maximum of $369 \mathrm{MPa}$, with about $45 \mathrm{MPa}$ higher than that of the $\mathrm{A}_{3}$ alloy. The $\mathrm{A}_{3}$ alloy contains $7.5 \mathrm{wt} . \% \mathrm{Cu}$, with a higher $\mathrm{Cu}$ content than the $\mathrm{A}_{2}$ alloy $(4.5 \mathrm{wt}$. $\% \mathrm{Cu})$. In as-solutionized microstructure of the $\mathrm{A}_{3}$ alloy, the amount of the survived eutectic $\theta$ phase at grain boundaries is much higher than that of the $\mathrm{A}_{2}$ alloy (Figure 8). During tension at $25^{\circ} \mathrm{C}$, because the amount of the $T_{\mathrm{Mn}}$ and $\mathrm{AlCu}_{3} \mathrm{Mn}_{2}$ particles in the $\mathrm{A}_{3}$ alloy precipitated during solutionizing is larger than that in the $\mathrm{A}_{2}$ alloy and its size is also finer, the YS of the $A_{3}$ alloy is higher than that of the $A_{2}$ alloy (Table 3), but more severe grain boundary brittleness in the $\mathrm{A}_{3}$ alloy that is induced by the survived $\theta$ phase at grain boundaries makes the matrix lose the ability to tolerate large plastic deformation at room temperature; thus, only with a smaller strain, the sample is fractured. As a result, the elongation of the $\mathrm{A}_{3}$ alloy (about 1.1\%) is much less than that of the $\mathrm{A}_{2}$ alloy (about 6.3\%), and hence, the UTS is also decreased. In case of tension at $300^{\circ} \mathrm{C}$, both the YS and UTS are increased with $\mathrm{Cu}$ content due to the increased precipitation hardening with the $\mathrm{Cu}$ content, consistent with the results in [28]. As concluded above, high temperature strength overridingly depends on the precipitation behavior during solutionizing. The number of particles precipitated during solutionizing is increased with $\mathrm{Cu}$ content in the alloy, and simultaneously, the particle size is decreased (Figure 3); the survived eutectic $\theta$ and $T_{\mathrm{Mn}}$ particles at the grain boundaries can also enhance the ability of grain boundaries to opposite plastic deformation at high temperature, and thus, the high temperature strength is considerably increased with $\mathrm{Cu}$ content in the alloy.

\section{Conclusions}

(1) A shell-core structure is found to form on primary $\alpha$-Al dendrites in $\mathrm{Al}-\mathrm{Cu}-\mathrm{Mn}$ alloys due to nonequilibrium solidification, in which the $\mathrm{Cu}$ content in the shell is much higher than that in the core. The area of the $\mathrm{Cu}$-rich regions (denoting the shell zones) is increased with $\mathrm{Cu}$ content in the alloy.

(2) A great amount of fine dispersoid Al-Cu-Mn particles are found to precipitate during the solutionizing course of the studied $\mathrm{Al}-\mathrm{Cu}-\mathrm{Mn}$ alloys. In the alloy with a low $\mathrm{Cu}$ content, only $T_{\mathrm{Mn}}\left(\mathrm{Al}_{20} \mathrm{Cu}_{2} \mathrm{Mn}_{3}\right)$ particles are precipitated. However, in the alloy with a high $\mathrm{Cu}$ content, $\mathrm{AlCu}_{3} \mathrm{Mn}_{2}$ particles are first demonstrated to precipitate besides $T_{\mathrm{Mn}}$. The AlC$\mathrm{u}_{3} \mathrm{Mn}_{2}$ phase has a simple cubic structure with $a=0.6904 \mathrm{~nm}$.

(3) This precipitation behavior is uneven. Besides the precipitation zones (PZs), there are no-particles zones (NPZs) and particle-free bands (PFBs) between PZs. The PZs in the as-solutionized microstructure are highly consistent with the $\mathrm{Cu}$-rich regions in the as-cast microstructure. It is the supersaturation of the $\mathrm{Cu}$ solute in the $\mathrm{Cu}$-rich regions and very low diffusion coefficient of manganese in the $\mathrm{Al}$ solution that drive the dispersoid precipitation of $T_{\mathrm{Mn}}$ and AlC$\mathrm{u}_{3} \mathrm{Mn}_{2}$ to occur in the Cu-rich regions during the solutionizing course.

(4) The evolution of redissolution and granulation of the eutectic $\mathrm{CuAl}_{2}$ phase during solutionizing leaves band areas where they are highly $\mathrm{Mn}$-poor. It is due to $\mathrm{Mn}$ poor that no precipitation of $T_{\mathrm{Mn}}$ particles takes place there, and thus, PFBs are formed between the PZs.

(5) Results of the tension test strongly demonstrate that, compared with the samples as-cast, the considerable increments in YS and UTS at $300^{\circ} \mathrm{C}$ of the samples as-solutionized and T6 tempered are almost completely contributed to the dispersoid precipitation of a great number of $T_{\mathrm{Mn}}$ and $\mathrm{AlCu}_{3} \mathrm{Mn}_{2}$ particles during solutionizing, and the precipitation behavior in the aging course has no or little contribution to it.

(6) High temperature strength of Al- $x w t . \% C u-1.0$ wt.\% $\mathrm{Mn}$ alloy is considerably increased with $\mathrm{Cu}$ content, which is closely tied with the increased number and simultaneously decreased size of $T_{\mathrm{Mn}}$ and $\mathrm{AlCu}_{3} \mathrm{Mn}_{2}$ particles precipitated during solutionizing.

\section{Data Availability}

The data used to support the findings of this study are included within the article.

\section{Conflicts of Interest}

The authors declare that they have no conflicts of interest.

\section{Acknowledgments}

This work was supported by the Jiangsu Key Laboratory Metallic Materials (Grant no. BM2007204) and the Fundamental Research Funds for the Central Universities (Grant no. 2242016k40011). The authors are also thankful to Sha-steel Iron and Steel Research Institute of Jiangsu Province for their useful assistance.

\section{References}

[1] G. Sha, R. K. W. Marceau, X. Gao, B. C. Muddle, and S. P. Ringer, "Nanostructure of aluminum alloy 2024: segregation, clustering and precipitation processes," Acta Materialia, vol. 59, no. 4, pp. 1659-1670, 2011. 
[2] D. M. Yao, W. G. Zhao, H. L. Zhao, F. Qiu, and Q. C. Jiang, "High creep resistance behavior of the casting $\mathrm{Al}-\mathrm{Cu}$ alloy modified by La," Scripta Materialia, vol. 61, no. 12, pp. 1153-1155, 2009.

[3] X. Li, K. Lei, P. Song et al., "Strengthening of aluminum alloy 2219 by thermo-mechanical treatment," Journal of Materials Engineering \& Performance, vol. 24, no. 10, pp. 3905-3911, 2015.

[4] A. K. Jha, S. V. S. N. Murty, K. Sreekumar, and P. P. Sinha, "High strain rate deformation and cracking of AA 2219 aluminum alloy welded propellant tank," Engineering Failure Analysis, vol. 16, no. 7, pp. 2209-2216, 2009.

[5] S. C. Wang and M. J. Starink, "Precipitates and intermetallic phases in precipitation hardening $\mathrm{Al}-\mathrm{Cu}-\mathrm{Mg}-(\mathrm{Li})$ based alloys," International Materials Reviews, vol. 50, no. 4, pp. 193-215, 2005.

[6] Y. L. Zhao, Z. Q. Yang, Z. Zhang, G. Y. Su, and X. L. Ma, "Double-peak age strengthening of cold-worked 2024 aluminum alloy," Acta Materialia, vol. 61, no. 5, pp. 1624-1638, 2013.

[7] X. X. Feng, A. M. Kumar, and J. P. Hirth, "Mixed mode I/III fracture toughness of 2034 aluminum alloys," Acta Metallurgica et Materialia, vol. 41, no. 9, pp. 2755-2764, 1993.

[8] D. Tsivoulas, J. D. Robson, C. Sigli, and P. B. Prangnell, "Interactions between zirconium and manganese dispersoidforming elements on their combined addition in $\mathrm{Al}-\mathrm{Cu}-\mathrm{Li}$ alloys," Acta Materialia, vol. 60, no. 13-14, pp. 5245-5259, 2012.

[9] Z. Q. Feng, Y. Q. Yang, B. Huang, M. H. Li, Y. X. Chen, and J. G. Ru, "Crystal substructures of the rotation-twinned $\mathrm{T}$ $\left(\mathrm{Al}_{20} \mathrm{Cu}_{2} \mathrm{Mn}_{3}\right)$ phase in 2024 aluminum alloy," Journal of Alloys and Compouds, vol. 583, pp. 445-451, 2014.

[10] Z. Shen, C. Liu, Q. Ding et al., "The structure determination of $\mathrm{Al}_{20} \mathrm{Cu}_{2} \mathrm{Mn}_{3}$ by near atomic resolution chemical mapping," Journal of Alloys and Compounds, vol. 601, no. 9, pp. 25-30, 2014.

[11] Z. Chen, P. Chen, and S. Li, "Effect of Ce addition on microstructure of $\mathrm{Al}_{20} \mathrm{Cu}_{2} \mathrm{Mn}_{3}$ twin phase in an $\mathrm{Al}-\mathrm{Cu}-\mathrm{Mn}$ casting alloy," Materials Science and Engineering: A, vol. 532, no. 3, pp. 606-609, 2012.

[12] Z. W. Chen, Q. Y. Fan, and K. Zhao, "Microstructure and microhardness of nanostructured $\mathrm{Al}-4.6 \mathrm{Cu}-\mathrm{Mn}$ alloy ribbons," International Journal of Minerals, Metallurgy, and Materials, vol. 22, no. 8, pp. 860-867, 2015.

[13] S. Wang, C. Li, and M. Yan, "Determination of structure of $\mathrm{Al}_{20} \mathrm{Cu}_{2} \mathrm{Mn}_{3}$ phase in Al-Cu-Mn alloys," Materials Research Bulletin, vol. 24, no. 10, pp. 1267-1270, 1989.

[14] W. J. Park and N. J. Kim, "Microstructural characterization of 2124 Al-SiCW composite," Scripta Materialia, vol. 36, no. 9, pp. 1045-1051, 1997.

[15] G. B. Johnston and E. O. Hall, "Studies on the Heusler alloys-II. The structure of $\mathrm{Cu}_{3} \mathrm{Mn}_{2} \mathrm{Al}$," Journal of Physics and Chemistry of Solids, vol. 29, no. 2, pp. 201-207, 1968.

[16] B. Li, Q. L. Pan, C. P. Chen, and Z. M. Yin, "Effect of aging time on precipitation behavior, mechanical and corrosion properties of a novel Al-Zn-Mg-Sc-Zr alloy," Transactions of Nonferrous Metals Society of China, vol. 26, no. 9, pp. 22632275, 2016.

[17] A. Munitz and C. Cotler, "Aging impact on mechanical properties and microstructure of Al-6063," Journal of Materials Science, vol. 35, no. 10, pp. 2529-2538, 2000.

[18] H. C. Liao, Y. Y. Tang, X. J. Suo et al., "Dispersoid particles precipitated during the solutionizing course of Al-12 wt $\% \mathrm{Si}-4$ wt $\% \mathrm{Cu}-1.2 \mathrm{wt} \% \mathrm{Mn}$ alloy and its contribution to high temperature strength," Materials Science and Engineering:A, vol. 699, pp. 201-209, 2017.

[19] S. Maâmar and M. Harmelin, "On the transitions of the icosahedral and decagonal phases towards equilibrium phases in Al-Cu-Mn alloys," Philosophical Magazine Letters, vol. 64, no. 6, pp. 343-348, 1991.

[20] S. M. Skolianos, T. Z. Kattamis, and O. F. Devereux, "Microstructure and corrosion behavior of as-cast and heattreated Al-4.5 Wt pct Cu-2.0 wt pct Mn alloys," Metallurgical Transactions A, vol. 20, no. 11, pp. 2499-2516, 1989.

[21] A.T Chen, L. Zhang, G. H. Wu, M. Sun, and W. C. Liu, "Influences of Mn content on the microstructures and mechanical properties of cast Al-3Li-2Cu-0.2Zr alloy," Journal of Alloys and Compounds, vol. 715, pp. 421-431, 2017.

[22] M. Chen and T. Z. Kattamis, "Dendrite coarsening during directional solidification of $\mathrm{Al}-\mathrm{Cu}-\mathrm{Mn}$ alloys," Materials Science and Engineering: A, vol. 247, no. 1-2, pp. 239-247, 1998.

[23] I. Häusler, C. Schwarze, M. U. Bilal et al., "Precipitation of $\mathrm{T}_{1}$ and $\theta^{\prime}$ phase in $\mathrm{Al}-4 \mathrm{Cu}-1 \mathrm{Li}-0.25 \mathrm{Mn}$ during age hardening: microstructural investigation and phase-field simulation," Materials, vol. 10, no. 2, p. 117, 2017.

[24] S. P. Ringer and K. Hono, "Microstructural evolution and age hardening in aluminium alloys: atom probe field-ion microscopy and transmission electron microscopy studies," Materials Characterization, vol. 44, no. 1, pp. 101-131, 2000.

[25] E. Cerri, E. Evangelista, and N. Ryum, "The relationship between microstructural and plastic instability in Al-4.0 wt pct Cu alloy," Metallurgical and Materials Transactions A, vol. 27, no. 10, pp. 2916-2922, 1996.

[26] E. Balducci, L. Ceschini, S. Messieri, S. Wenner, and R. Holmestad, "Thermal stability of the lightweight 2099 Al$\mathrm{Cu}-\mathrm{Li}$ alloy: tensile tests and microstructural investigations after overaging," Materials \& Design, vol. 119, pp. 54-64, 2017.

[27] Z. Gao, J. H. Chen, S. Y. Duan, X. B. Yang, and C. L. Wu, "Complex precipitation sequences of $\mathrm{Al}-\mathrm{Cu}-\mathrm{Li}-(\mathrm{Mg})$ alloys characterized in relation to thermal ageing processes," Acta Metallurgica Sinica, vol. 29, no. 1, pp. 94-103, 2016.

[28] D. H. Xiao, J. N. Wang, D. Y. Ding, and S. P. Chen, "Effect of $\mathrm{Cu}$ content on the mechanical properties of an $\mathrm{Al}-\mathrm{Cu}-\mathrm{Mg}-\mathrm{Ag}$ alloy," Journal of Alloys and Compounds, vol. 343, no. 1, pp. 77-81, 2002. 


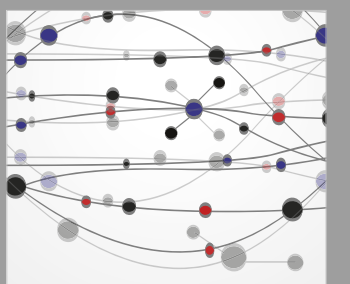

The Scientific World Journal
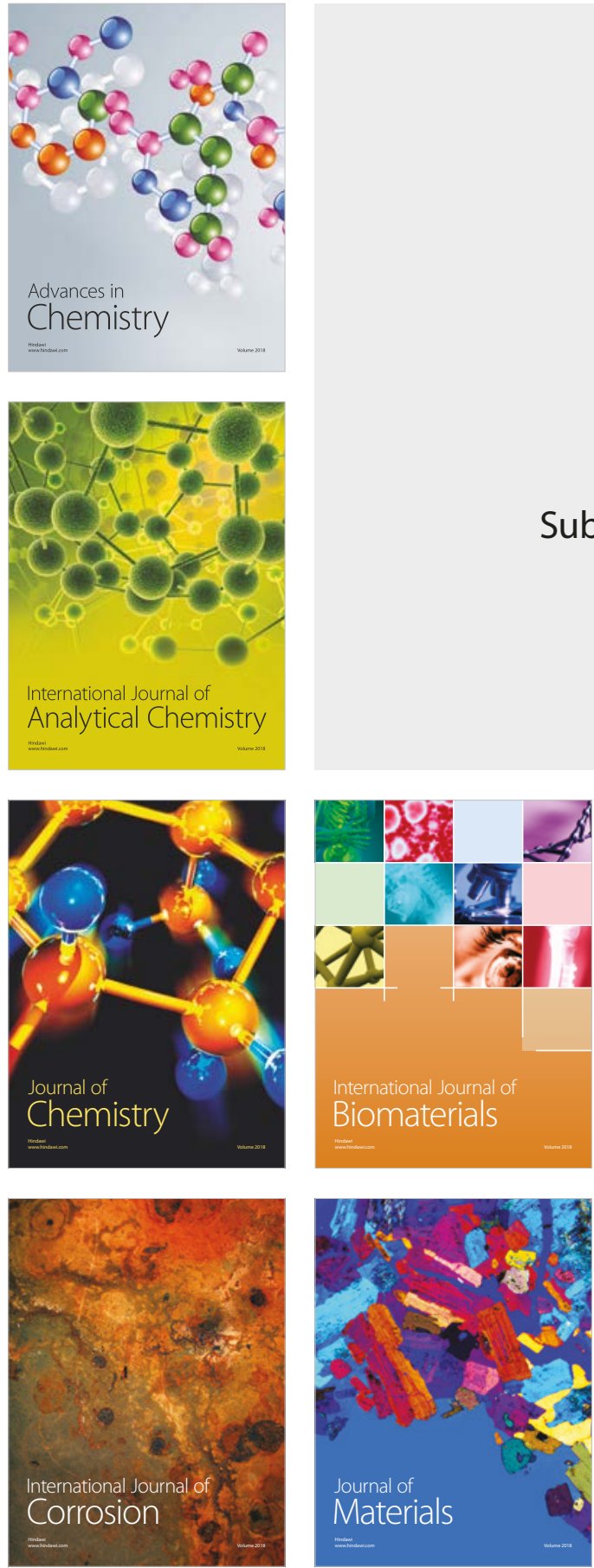

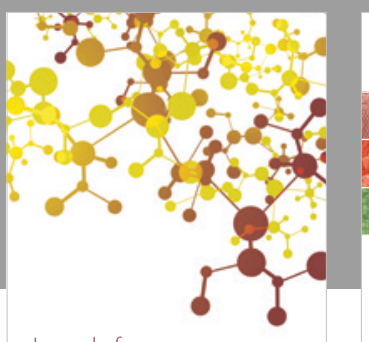

Journal of

Applied Chemistry
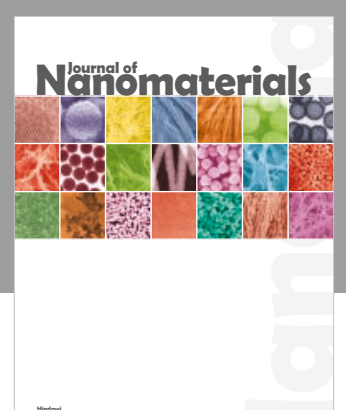

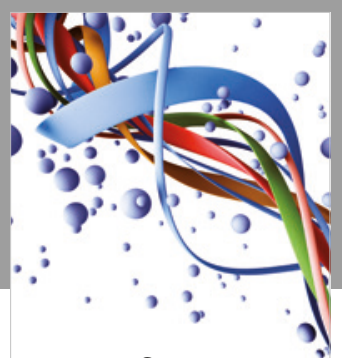

Scientifica

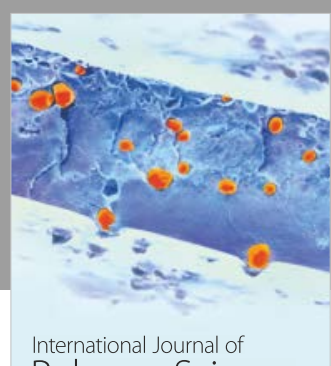

Polymer Science

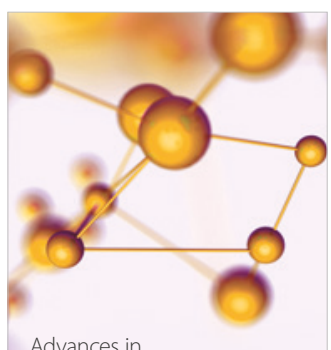

Physical Chemistry
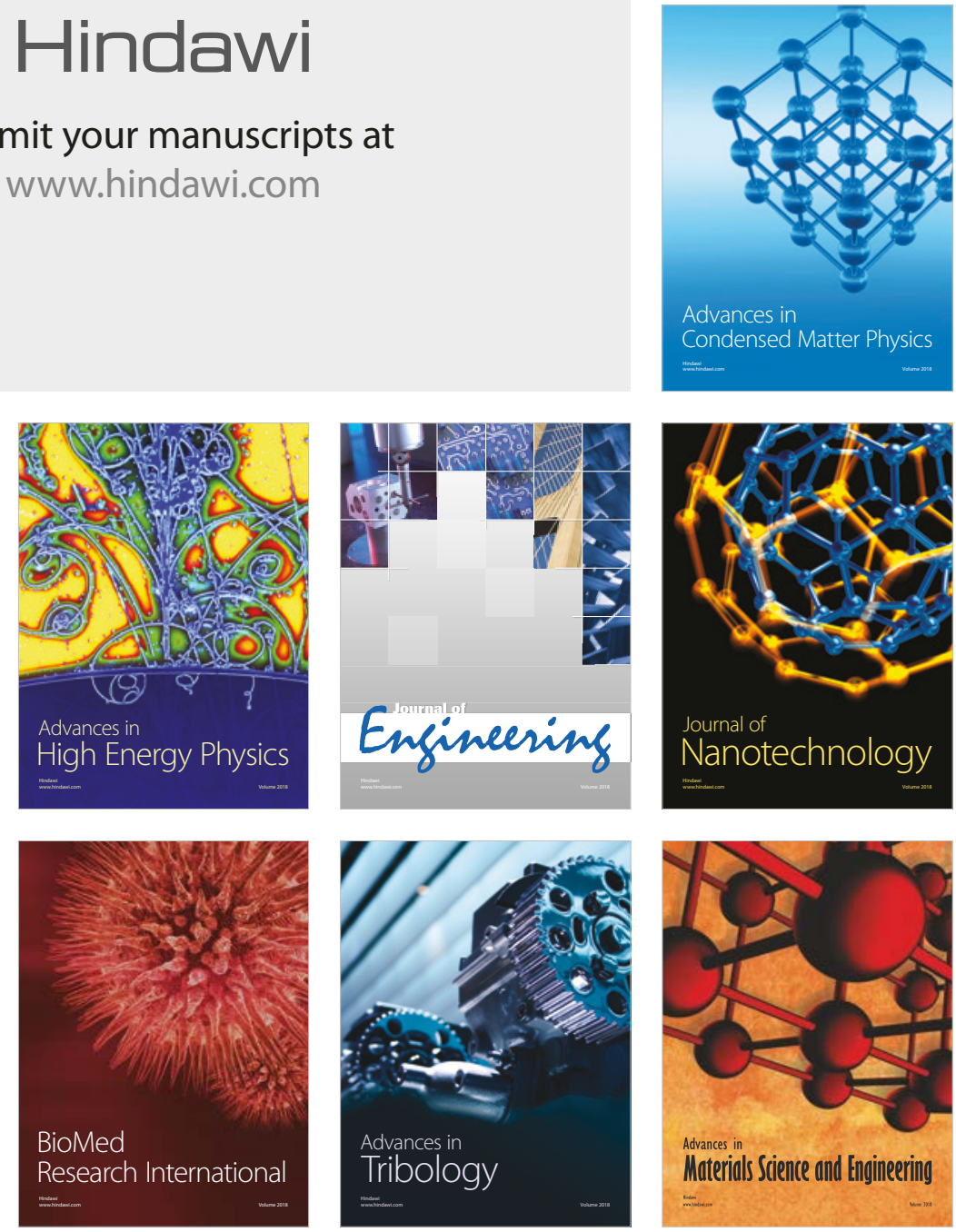